\title{
Katılımlı Yaklaşımla Ortaya Çıkarılan Örtük Bilginin Kodlanmış Bilgiden Farkının Ortaya Konulması*
}

Neslihan Kulözü-

\author{
Uzunboy ${ }^{1}$
}

ORCID: 0000-0002-1945-2635

\author{
Gürel Çetin²
}

ORCID: 0000-0003-3568-6527
O. Cenk Demiroğlu ${ }^{3}$

ORCID: 0000-0001-7012-4111

\section{Öz}

Bu çalışma Prof. Dr. İlhan Tekeli'nin kodlanmış ve örtük bilgiyi ele alışı ile bu bilgi türleri arasındaki farklara ilişkin yaklaşımı temel alınarak geliştirilmiştir. Buradan hareketle çalışma günümüz dünyasında demokratik bir insan hakkı olarak tanımlanan katılımın yöntemsel bir yaklaşım olarak benimsendiği bilgi üretim sürecinde elde edilen örtük bilginin, kodlanmış bilgiden farklı olacă̆ı varsayımı üzerine kurulmuştur. Bu bağlamda çalışmanın amacı yerelin örtülü bilgisi ile ikincil kaynaklara dayah bilgi üretme süreçleri ile elde edilen bilimsel bilginin karşılaştırılması yoluyla, katılımlı yöntemsel yaklaşımla elde edilen bilginin nasıl fark yarattığının ortaya konulmasıdır. Bu amaç doğrultusunda çalışma kapsamında Erzurum'da Kış Turizminin İklim Değişikliğine Uyumlanma Stratejilerinin Katılımlı Yöntemsel Yaklaşımla Belirlenmesi başlıklı projenin farklı aşamalarında GZFT analizi tekniğiyle üretilen bilgi karşılaştırllacaktır. Bu bağlamda karşılaştırılacak GZFT analizlerinden ilki projenin ilk aşamasında (Kasım 2018 - Ocak 2019), Erzurum'da kış turizminin mevcut durumunun analiz edilmesi amacıyla ikincil kaynaklara dayah olarak, ikincisi ise aynı amaçla ilgili aktörlerin katılımı ile gerçekleştirilen çalıştayda (Haziran 2019) elde edilen bilgi ile üretilmiştir. Birbirinden bağımsız olarak aynı amaçla ancak farklı yaklaşımlarla üretilen GZFT analizlerinin karşılaştırılması ile bu çalışmanın sonucunda katılımlı yöntemsel yaklaşımla ortaya çıkarılan yerelin bilgisinin kodlanmış bilgiden farkının ortaya konulması yoluyla katılımın önemine vurgu yapılacaktır.

Anahtar Kelimeler: Katılım, bilgi üretme, kodlanmış bilgi, örtük bilgi, GZFT analizi

\footnotetext{
* Bu çalışma TÜBITTAK tarafından desteklenen 118K191 kodlu projeden üretilmiştir. Katkılarından dolayı TÜBİTAK'a teşekkürü bir borç biliriz.

${ }^{1}$ Doç.Dr., Atatürk Üniversitesi, E-mail: nkulozu@atauni.edu.tr

${ }^{2}$ Doç. Dr., İstanbul Üniversitesi E-mail: gurelc@istanbul.edu.tr

${ }^{3}$ Doç. Dr., Umeå Üniversitesi E-mail: cenk.demiroglu@umu.se

idealkent @ Kent Araştırmaları Dergisi (Journal of Urban Studies) 



\title{
Determining Difference of Implicit Knowledge Obtained through Participatory Approach with Coded Knowledge
}

\author{
Neslihan Kulözü- \\ Uzunboy 4
}

ORCID: 0000-0002-1945-2635

\author{
Gürel Çetin ${ }^{5}$ \\ ORCID: 0000-0003-3568-6527
}

O. Cenk Demiroğlu

ORCID: 0000-0001-7012-4111

\begin{abstract}
This study has been developed on the basis of Prof. Dr. Ilhan Tekeli's approach to coded and implicit knowledge and the differences between these types of knowledge. From this point of view, the study is based on the assumption that the implicit knowledge obtained through participatory approach will be different from the coded knowledge. In this context, the aim of the study is to reveal how the generated knowledge makes a difference by comparing with the coded knowledge. For this purpose, within the scope of the study, the knowledge produced with the SWOT Analysis technique at different stages of the project titled "Determination of Winter Tourism Adaptation Strategies in Erzurum with a Participatory Methodological Approach" have been compared. The first of the SWOT analyzes has been produced in the first stage of the project based on secondary sources for the purpose of analyzing the current situation of winter tourism in Erzurum. For the same purpose, second SWOT analysis has been produced in the workshop realized with the participation of relevant actors. At the end, this study has emphasised the importance of participation and knowledge generation process by revealing the difference of the generated knowledge from the scientific knowledge extracted from the literature.
\end{abstract}

Keywords: Participation, knowledge generation, coded knowledge, implicit knowledge, SWOT analysis.

\footnotetext{
${ }^{4}$ Assoc. Prof., Atatürk University, E-mail: nkulozu@atauni.edu.tr

${ }^{5}$ Assoc. Prof., İstanbul University E-mail: gurelc@istanbul.edu.tr

${ }^{6}$ Assoc. Prof., Umeå University E-mail: cenk.demiroglu@umu.se

idealkent @ Kent Araştırmaları Dergisi (Journal of Urban Studies) 


\section{Giriş}

Günümüz dünyasının içinde olduğu çok yönlü dönüşüm sürecini açıklamak için kullanılan senaryolardan birisi, diğer senaryolar içerisinde de merkezi konuma sahip olan Sanayi Toplumundan Bilgi Toplumuna Geçiştir. Tekeli (2010)'nin ifadesiyle sanayi toplumunda şeyleşen insanın kapasitesi kaslarının uzantısı olarak geliştirilmişken, bilgi toplumunda beyninin uzantısı olarak geliştirilmektedir. Sanayi toplumundan bilgi toplumuna geçiş sürecinde yaşanan bu ve benzeri değişimlerin etkisiyle insanların yaşam kalıpları yeniden tanımlanmakta, üretimin niteliği ve toplumun örgütlenme biçimi değişmektedir. Bütün bunların sonucunda ise bilgi ile üretim ilişkisinin kurulma biçimi değişmekte ve bilgiyi bilenle ilişki içinde anlamaya yönelik adımlar atılmaktadır (Tekeli, 2010). Bilgi ile üretim ilişkisinin kurulma biçimindeki değişme kapsamında, bilginin de emek ve kapital gibi temel üretim faktörü haline geldiği, bilginin üretiminin de iş içinde olmaya başladığı ve üretime bağlandığı belirtilmelidir (Arrow, 2000; Luque, 2001; Tekeli, 2010). Bu çalışmada bilginin bilenle ilişkisini anlama çerçevesinde kodlanmış bilgi ile örtük (tacit) bilgi ${ }^{7}$ ve katılımlı bilgi üretim süreçlerine odaklanılmaktadır.

Bilgi insanın kapasiteleri tarafından üretilmektedir. İnsanın bu yeteneği kendi dışındaki dünya ile ilişki kurması ve bu ilişkileri denetleyebilmesini sağlamaktadır. Bu bağlamda bilgiye yaklaşımda en önemli kırılma noktası, insanlık tarihinin en önemli dönüm noktalarından biri olan Aydınlanma ile başlayan, Bilimsel Devrim, Sanayi Devrimi ve Fransiz Devrimi ile devam ederek insanlığı modernleşmeye ulaştıran süreçte yaşanmıştır. Bu dönemde, evrensel geçerliliği olan, nesnel sosyal bilim yasalarının belirlenebileceği ve bunların insan eylemlerine doğru yolu göstereceği kabul edilmiştir. Araçsal aklın insan eylemlerini en doğru şekilde yönlendirebilecek olduğu kabulü ise demokratik karar süreçlerine duyulan ihtiyacı ortadan kaldırmaktadır (Tekeli, 2010:130). Dolayısıyla 19. yy.'da bilimsel bilginin dogmatik bilgi karş1sinda üstünlük kurmasıyla insanın özgürlügünü kendi ellerine veren araçsal akılcılık, insanlığın geldiği noktada "demokratik politik öğeler üzerinde bir tehdit oluşturmuştur (Tekeli, 2010, s.130)". Diğer bir ifadeyle teknik akıl politik içeriğinden vazgeçememiştir. Böylece, bilimsel bilginin araçsal akılcılık anlayışı

\footnotetext{
${ }^{7}$ Gizil (implicit) ve bilenden ayrılamayan (embodied) bilgi olarak da adlandırılmaktadır (Tekeli, 2010).
} 
içinde demokratik seçmelere yer bırakmayacak şekilde kullanılmasıyla ortaya güç ilişkisi çıkmıştır. Bilginin genelleştirilmiş bir kapasite olduğunun kabul edilmesiyle güç ile ilişkisi de kabul edilmektedir. ${ }^{8}$

Dolayısıyla aydınlanmanın insanı dini dogmaların baskısından kurtararak özgürleştiren ancak araçsallaşarak insanı var olan düzene hapsedici hale gelen akılcılı̆̆ı insanı ikinci kez özgürleştirmek görevi ile karşı karşıya kalmıştır. Ancak bu defa özgürleştirme görevini toplum bilimin nesnel olarak değil, ancak öznellerarasılılıklara dayalı olarak kurulabileceği kabulüne dayanan eleştirel akılcılık üstlenmiştir. Var olan güç ilişkilerini pekiştirmek yerine değişebilecek olanı değiştirmeyi amaçlayan bu yaklaşımın toplum bilimleri ve bilgiyi ele alışı içerisinde, araçsal akılcılıktan farklı olarak, bilimsel bilgi demokrasiyi dışlayıcı konumda görülmez. Çünkü eleştirel gerçekçiliğe göre gözlenen olgular daha önceki tarihsel süreç içerisinde öznellerarası uzlaşmanın sonucudur ve yeni uzlaşmalarla değisşebilir (Tekeli, 2010). Böylece öznellerarası uzlaşmaların sağlanması yoluyla değişebilecek olan değişir (Sayer, 1992). Ayrıca öznellerarası uzlaşımların ortaya koyduğu çözümleri iletişimsel rasyonellik gerçekleştirir; böylece hem iletişimsel rasyonellik gerçekleştirilir, hem de rasyonellik ile demokrasi arasında uyumsuzluk ortadan kalkmış olur (Tekeli, 2010). İletişimsel rasyonalite, temel olarak, modernizmin araçsal rasyonalitesinde, birbirinden ayrılmış olan bilimin doğrusu ile ahlakın iyisi, yani teori ile pratiği ilişkilendirilmeye çalışmaktadır (Kulözü, 2011).

Sanayi toplumundan bilgi toplumuna geçiş süreci ve bu süreçte yaşanan araçsal akılcılıktan iletişimsel akılcılığa geçiş gibi değişimlerin etkisiyle bilgiye yaklaşım da değişmiş; bilimsel bilgiden farklı olarak bileninden kolayca ayrılamayan örtük bilginin önemi anlaşılmıştır. Bu geçiş nesnel bilgiden öznellerarası uzlaşmanın bilgisine geçiş olarak da adlandırılabilmektedir.

Bilgi üretim sürecinde, temel olarak, insan kendi dışındaki dünyadan ham veriler elde eder. Bu veriler kodlanmalarının ya da sembolleştirilmelerinin ardından işlenerek enformasyona ve sonra da kavrama dönüştürülür. $\mathrm{Bu}$ kavramlar aracılığıyla dış dünya basitleştirilmiş olarak temsil edilebilmektedir. Ayrıca bilginin kodlanması ya da sembolleştirilmesi sayesinde iletişim kurulabilmekte ve bilgi aktarılarak biriktirilebilmektedir (Tekeli, 2010, ss. 111-112). Dolayısıyla bilenden kolayca ayrılabilen kodlanmış bilgi kodlar ve

\footnotetext{
${ }^{8}$ Bu ilişki Tekeli (2010)'ye göre, bilginin demokratik seçmelere yer bırakmayacak şekilde kullanılmasına ilaveten 3 farklı şekilde daha kurulmaktadır. Bunlardan birincisi, bilginin genelleştirilmiş bir kapasite olmasıyla ilgilidir; bilginin denetlenmesi de güç oluşturmaktadır. İkincisi, bilginin toplumun her noktasında iktidarı yeniden üretme aracı olarak ele alınmasıdır. Üçüncüsü ise bilginin bir eylemi yönlendirmekte kullanılması halinde ortaya çıkmaktadır.
} 
sembollerle ikincil kaynaklara kaydedilmiş bilgidir. Kodlanmış bilgi saklanabilir, biriktirilebilir, aktarılabilir ve diğer bilgilerle bütünleştirilebilir. Ancak günümüzde artık bilgi sadece kodlanmış ve bilenden kolayca ayrılabilen bilgi olarak kabul edilmemektedir (Hellstom ve Raman, 2001). Kodlanmış bilgiden farklı olarak örtük bilgi kodlanmamış olduğundan ancak yakın ilişki içinde yaşayarak ve görerek elde edilebilmektedir (Stiglitz, 2000). Örtük bilginin kodlanmış bilgiye dönüşebilecek bir kısmı bulunmakla beraber bir kısmının niteliği kodlanmasına olanak vermemektedir. Bu nedenle de günümüz dünyasında örtük bilginin taşınabilecek, saklanabilecek, biriktirilebilecek ve aktarılabilecek hale getirilmesi önemli bir sorun olarak karşımıza çıkmaktadır. Diğer taraftan örtük bilgiye ilişkin bu özellik yerel olma eğilimini attırmakta ve bilgi ile demokrasi ilişkisine yeni açılımlar getirmektedir (Tekeli, 2010). Çünkü bilimsel bilgi denildiğinde genel olarak evrensel geçerliliği olan bilgi anlaşılmakta ve yerel bilgi bilim dışı olarak kabul edilmektedir. Bu nedenle bilgi genel bilgi ve yerel bilgi olarak 2 başlık altında incelenebilir. Genel bilgi kültürler üstü, her yerde ve her zaman geçerliliği olan bilgidir. Yerel bilgi ise yerellik içinde geçerli olan, yerelin özgün koşullarından beslenen bilgidir (Tekeli, 2010). Buradan hareketle bir yerelde geçerli olan bilginin, başka bir yerelde geçerli olmayabileceği, yani bilginin bağlam bağımlılığı da, kabul edilmelidir.

Modernleşme sürecinde evrensel bilgi ve yerel bilginin işlevlerinin farkl1lığının bilincinde olunmadığı dönemde yerelin bir sorununa yönelik çözüm yollarının dıştan empoze edilmesine oldukça sık rastlanmıştır. Araçsal akılc1lığın yönlendiriciliğinde gerçekleşen bu uygulamaların yansıması planlama alanında, kentlere evrensellik iddiasına sahip kestirimde bulunan kuramlarla yaklaşılması şeklinde deneyimlenmiştir (Tekeli, 2012). Ancak böyle bir yol izlendiğinde bir sorunun çözüm yolları, yerel öğrenme süreçlerine kapalı bir şekilde aranmakta, yerel karar vericiler pasifleştirilmekte ve yerel aktörlerin öğrenme kapasiteleri devre dışı bırakılmaktadır. Ayrıca dışarıdan empoze edilen bilgi yerelle uyumlanamayarak, gelişmeye kapalı kalmaktadır. $\mathrm{Bu}$ doğrultuda da planlama alanında, 1960'ların ikinci yarısından sonra, yerelin katılımını önceleyen ve böylece öznellerarası uzlaşmayı ve iletişimsel rasyonaliteyi gerçekleştiren planlama yaklaşımları kabul görmeye başlamıştır $(\mathrm{Ku}-$ lözü, 2011). Dolayısıyla planlama alanında deneyimlendiği gibi bilginin dışarıdan empoze edilmesi yerine yatay ilişkiler içinde yayılmasına öncelik verilmelidir. Diğer bir ifade ile katılıma, planlama ve diğer bilgi ve karar üretme süreçlerinde önemli roller verilmelidir. Katılımlı yaklaşımların benimsendiği 
süreçlerde yayılan bilgi gelişme ve yaratıcılığı beraberinde getirmektir (Tekeli, 2010).

Bu bağlamda sanayi devriminin ardından kentlerde ortaya çıkan ve insan sağlı̆̆ ve hayatını tehdit eder boyutlara ulaşan sorunların çözümü için araç olarak geliştirilen akılcı kapsamlı planlama yaklaşımı (Kulözü, 2015a) özellikle 1960'lı yıllardan itibaren sıklıkla eleştiri konusu olmuştur (Kulözü; 2011; Ersoy, 2017). Tepki olarak geliştirilen ve katılımın amaç olarak kavramsallaştırıldığı planlama yaklaşımlarından bazıları müzakereci ve işbirlikçi, iletişimsel, pratik tepkisel, taahhütçü ve stratejik planlamadır (Kulözü, 2011; Kulözü ve Tekeli, 2014). Bunlardan, önceleri yapısal planlama olarak da anılan, stratejik planlama yaklaşımı 1980'li yıllarda dünyada yaşanan liberal politikaların hâkim olması ve postmodernist akımların yaygınlaşması gibi gelişmeler sonucunda yeniden tanımlanmıştır. Stratejik planlamanın o güne kadar gelişmiş diğer planlama yaklaşımlarına göre farklı özellikleri arasında planlama sürecine farklı toplum kesimlerinin katılımı ve GZFT analizi yer almaktadır (Bryson ve Roering, 1987; Gedikli, 2012; Ersoy, 2017).

Katılım kavramı 1960'ların ikinci yarısından sonra dünyada yaşanan dönüşümlere paralel olarak planlama ve diğer pek çok siyasal ve yönetsel alanda yaygın olarak kullanılmaya başlanmıştır (Kulözü, 2011). Bu bağlamda katılım aktörlerin resmi ve resmi olmayan mekanizmalarla direkt olarak karar verme sürecine dâhil olması olarak tanımlanmıştır (Burke, 1979). Günümüzde insanın kendisi ve yaşam çevresine ilişkin kararlara katılımı demokratik hak olarak kabul edilmektedir (Kulözü, 2012; Kulözü, 2014; Kulözü, 2016b). Bu bağlamda her türlü karar ve bilgi üretme sürecinde öznellerarası uzlaşmayı sağlamanın yolu olarak katılım iletişimsel rasyonalitenin gerçekleştirilmesi ve örtük bilginin ortaya çıkarılması anlamına da gelmektedir. Ancak katılım farklı düzeylerde gerçekleşebilmektedir (Arnstein, 1969; Tekeli, 1991; Pretty, 1995; Cornwall, 1996; White, 1996; Kulözü, 2011) ve bu düzeylerden bazılarında öznellerarası uzlaşmayı sağlama hedefinden uzaklaşarak araçsallaşmaktadır (Kulözü, 2014; Kulözü, 2016b). ${ }^{9}$

Katılımın gerçekleştiği düzeye bağlı olarak katılımlı süreçlerde bilgi akışının yönü de değişmektedir. Araçsallaşmış bir katılımın gerçekleştiği süreçlerde tek yönlü bir bilgi akışı söz konusudur. Diğer taraftan iletişimsel rasyo-

\footnotetext{
${ }_{9}$ Tekeli (1991)'nin planın halka benimsetilmesi ve katılım yoluyla plancının bilgilenmesi düzeylerinde tanımladığı katılım düzeylerinde katılım araçsallaşmış bir katılım iken; plan kararlarına halkın katılması, eleştirel gerçekçiliği gerçekleştirme yolu olarak katılım ve paylaşmanın değil, yaratmanın heyecanına katılma düzeylerinde tanımladığı katılım, öznellerarası uzlaşmayı sağlamayı hedefleyen katılımcı sürecin amacı olarak kavramsallaştırılmıştır (Kulözü, 2011).
} 
nalite temelinde gelişen katılımlı süreçlerde katılımı sağlamanın amacı öznellerarası uzlaşmayı sağlamak, ahlakın iyisi ile bilimsel bilginin doğrusunu bir araya getirmek ve birlikte öğrenerek birlikte üretmektir. Iletişimsel rasyonaliteyi gerçekleştiren katılımlı süreçte çift yönlü bir bilgi akışı söz konusudur ve karşılıklı etkileşim ve iletişim gelişmektedir (Kulözü ve Tekeli, 2014; Kulözü, 2016a). Katılımın araçsallaştığı sürecin meşruiyet kaynağı bilimsel bilgi iken, katılımın amaç olduğu süreç meşruiyetini öznellerarası uzlaşma ve bilgiden almaktadır. Ancak burada bahsedilen yalnızca bilimsel yani kodlanmış bilgi değildir; katılımlı planlama sürecinde örtük bilgi de çok önemli bir kaynak oluşturmaktadır (Kulözü, 2011).

Katılım ile birlikte stratejik planlamayı tanımlamak için kullanılabilecek bir diğer kavram GZFT analizidiri ${ }^{10}$. GZFT analizi iç çevredeki güçlü ve zayıf yönler ile dış çevredeki, diğer bir ifade ile yerleşimin dışında bulunan, firsatlar ve tehditlerin sistematik olarak analiz edilmesidir (Gedikli, 2012; Ersoy, 2017). Güçlü ve zayıf yönler ile firsatlar ve tehditler sadece mekânsal alanda değil sosyal, kültürel, ekonomik, yasal ve yönetsel vb. alanların tamamına ilişkin olabilmektedir. Kısaca, planlama alanında GZFT analizi plana konu olan bölge ise ulusal ve uluslararası, kent ise bölgesel, ulusal ve uluslararası bağlamdaki firsat ve tehditler ile bölgenin veya kentin kendisine ilişkin güçlü ve zayıf yönlerin değerlendirilmesidir. Çevresel bir analiz olarak GZFT analizinde destinasyonların mikro anlamda güçlü yönleri ve zayıflıkları ile makro anlamda firsatları ve olası tehditler sıralanmaktadır.

Bu çalışma kapsamında örneklenen GZFT analizleri “Erzurum'da Kış Turizminin İklim Değişikliğine Uyumlanma Stratejilerinin Katılımlı Yaklaşımla Belirlenmesi" başlıklı proje kapsamında, projenin farklı aşamalarında üretilmiş̧ir. Proje kapsamında stratejik planlama yaklaşımı izlenmektedir. Bu bağlamda projenin ilk aşamasında Erzurum'da kış turizminin mevcut durumu tespit edilmiş, elde edilen bilginin sistematik bir biçimde sunulabilmesi ve projenin sonraki aşamalarında yönlendirici olabilmesi için GZFT analizi yapılmıştır. Diğer taraftan stratejik planlama yaklaşımının ikinci aşaması olarak Erzurum'da kış turizmi sektörünün aktörleri belirlenmiştir. Ardından aktörlerin katılımı ile Erzurum'da kış turizminin mevcut durumunun analiz edilmesi için odak grup çalışması yapılmıştır. Bu kapsamda düzenlenen çalı̧̧tayda katılımlı yaklaşımla üretilen bilgi GZFT yöntemiyle organize edilmiştir.

${ }^{10}$ GZFT ülkemizde yaygın olarak İngilizce karşılığı olan SWOT kelimesi ile anılmaktadır. 
Dolayısıyla proje kapsamında birincisi ikincil kaynaklara dayalı olarak, ikincisi ise aktörlerin katılımıyla ortaya çıkarılan yerelin bilgisine dayalı olarak 2 farklı GZFT analizi üretilmiştir. Bu çalışmanın amacı da birbirinden bağımsız olarak ancak aynı amaçla farklı bilgi kaynaklarından yararlanılarak üretilen GZFT analizlerinin ${ }^{11}$ karşılaştırılması yoluyla, bilgi üretme sürecinde katılımın ve elde edilen örtük bilginin nasıl fark yarattığının ortaya konulmasıdır. Çalışma kapsamında sunulan GZFT analizleri araç olarak ele alınmıştır. GZFT analizlerinin amacı değil, nasıl farklılık gösterdikleri çalışmanın odağını oluşturmaktadır. Bu amaç doğrultusunda çalışmanın izleyen bölümünde araştırmanın materyal ve metodolojisinin sunulmasının ardından, GZFT analizleri sunulacaktır. Sonraki bölümde GZFT analizleri karşılaştırılacak ve çalışma sonuç bölümü ile tamamlanacaktır.

\section{Materyal ve Metodoloji}

$\mathrm{Bu}$ çalışmanın materyalini aynı projenin farklı aşamalarında üretilen GZFT analizleri oluşturmaktadır. GZFT analizlerinden ilki, projenin Kasım 2018Ocak 2019 tarihleri arasında ikincil kaynaklara dayalı olarak üretilirken, ikincisi GZFT analizi ilkinden bağımsız bir şekilde Haziran 2019 tarihinde Erzurum'da düzenlenen çalıştayda katılımlı yöntemsel yaklaşımla üretilmiştir. Bu nedenle, GZFT analizlerinin elde edilmesinde kullanılan yaklaşımlar ile bu çalışmada izlenen yola açıklık getirilecektir.

İlk GZFT analizinin üretilmesinde Erzurum'un turizm potansiyeli ve Erzurum'da kış turizmine ilişkin (Altaş vd., 2015; Bayraktar vd., 2017; Büyükşehir Belediyesi Erzurum Spor, 2019; Ejder3200 Word Ski Center, 2019; Elmas vd., 2013; Koca vd. 2007; Korgavuş, 2017; Koşan ve Güneş, 2008; KUDAKA, 2014, KUDAKA 2019a, KUDAKA 2019b; Kulözü, 2015b; Kulözü-Uzunboy, 2017; Soyak, 2013; Erzurum Valiliği, 2019;2019; Erzurum Il Kültür ve Turizm Müdürlüğü, 2019; Üniversite Sporları Federasyonu, 2012; Yurttaş vd. 2008) kaynaklar ile birlikte daha önce Erzurum ve çevresinde kış turizmi gelişimi için yapılan çalışmalardan (Çetin ve Demiroğlu, 2017) faydalanılmıştır.

\footnotetext{
${ }^{11}$ GZFT analizlerinin proje ekibinde yer alan farklı araştırmacılar tarafından üretilmiş olması, katılımlı yaklaşımla elde edilen bilginin GZFT yöntemiyle sistematik hale getirilmesi aşamasında ilk üretilen GZFT analizinden etkilenme riskini ortadan kaldırmıştır.
} 
İkinci GZFT analizi ise 21 Haziran 2019 tarihinde Atatürk Üniversitesi'nde kış turizmi sektöründen 20 aktörün katılımı ile gerçekleştirilmiştir. ${ }^{12} \mathrm{~K}$ sş turizminin mevcut durumuna ilişkin yerelin örtülü bilgisini ortaya çıkarmayı amaçlayan çalıştayda arama konferansı yöntemi kullanılmıştır. Katılımlı olarak yönetilen gelecek planlama çalışması yöntemi olan arama konferansı yönteminin ilk iki aşaması bu çalıştayda uygulanmıştır. Çalıştayın birinci aşamasında, katılımclarla birlikte Erzurum'daki turizm faaliyetlerini bugün ve gelecekte etkilemeye devam edecek çevre şartlarının, gidişatlarının, oluşumların ve akımların tespiti ve değerlendirmesi yapılmıştır. İkinci aşamada ise katılımcılarla birlikte Erzurum'daki turizm faaliyetlerinin bugünkü durumunun tespiti ve değerlendirmesi yapılmıştır. Her iki aşamada, katılımcıların görüşleri önceliklendirilerek ortaklaştırılmıştır. Böylece çalıştayda aktörlerin katılımı ile üretilen yerelin bilgisi GZFT analizi yöntemi kullanılarak organize edilmiştir. ${ }^{13}$

İkincil kaynaklara bağlı olarak elde edilen GZFT analizi ile katılımlı yöntemsel yaklaşım izlenerek üretilen GZFT analizi bu çalışmanın amacı doğrultusunda karşılaştırılacağından, ortaklıklarını ve farklılıklarını gösterecek şekilde organize edilerek Tablo 1, 2, 3 ve 4'de sunulmuştur.

\section{Kodlanmış Bilgiye Dayalı Üretilen ve Katılımlı Yöntemsel Yaklaşımla Üretilen GZFT Analizleri}

\section{İkincil Kaynaklardan Elde Edilen Kodlanmış Bilgiye Dayah Olarak Üretilen GZFT Analizi}

Kodlanmış bilgiye dayalı olarak üretilen GZFT analizine göre, Erzurum ilinin kış turizmi için güçlü yönleri kar kalitesi ve yapay karlama olanakları, iklim özellikleri ve uzun sezon, uzun ve çeşitli pistler, gece kayağı olană̆ı, ulaşılabilirlik, alternatif turizm potansiyeli, tanınırlık, kış turizmi altyapısı, karar vericilerin ilgisi başlıkları altında toplanmıştır (Tablo 1). Zayıf yönler ise halktan kopuk turizm gelişimi, aracıların eksikliği, bütüncül destinasyon yönetimi eksikliği, tanıtım ve pazarlama eksikliği, turistik ürün eksikliği, hava kirliliği, kış turizmi üstyapısı ve yatırımların eksikliği, insan sermayesi eksikliği ile veri toplama ve arşivleme eksikliği başlıkları altında kategorize edilmiştir (Tablo 2). Erzurum ilinde kış turizmi aynı zamanda makro çevredeki

\footnotetext{
${ }^{12} \mathrm{Bu}$ çalışmanın parçası olduğu proje kapsamında yapılan aktör analizi sonucunda Erzurum'da Kış Turizmi sektörünün 55 aktörü olduğu belirlenmiş ve aktör olarak belirlenen kurum ve kuruluşlardan temsilciler çaliştaya davet edilmiştir.

${ }^{13}$ Çalıştay Prof. Dr. Anlı Ataöv'ün moderasyonunda gerçekleştirilmiştir. Katkılarından dolayı teşekkürü borç biliriz.
} 
bazı fırsat ve tehditlerden de etkilenmektedir. Çalışma kapsamında belirlenen firsatlar ulusal plan ve politikalar, kış turizmi pazarında iyileşme, proje ve yatırımlar, toplumsal yapı, alternatif turizm potansiyeli ile küresel ısınma ve iklim değişikliğidir (Tablo 3). Tablo 4 'de de özetlendiği gibi Erzurum ilinde turizm gelişimi önünde bazı tehditler de mevcuttur. Bu tehditler, toplumsal yapı, güvenlik tehditleri, doğal afetler ve küresel ısınma başlıkları altında toplanmıştır.

\section{Katılımlı Yöntemsel Yaklaşımla Ortaya Çıkarılan Yerelin Bilgisine} Dayalı Olarak Üretilen GZFT Analizi

Erzurum'da kış turizminin mevcut durumunu ortaya koymak amaciyla düzenlenen çalıştayda yerelin bilgisi odak grup tekniğiyle ortaya çıkarılmıştır. Elde edilen bilgiler GZFT analizi tablolarında (tablo 1,2,3,4) katılımlı yöntemsel yaklaşımla üretilen Erzurum ilinin kış turizmi için güçlü yönleri, zayıf yönleri, fırsatları ve tehditleri alt başlıkları altında sunulmuştur. Bunlardan güçlü yönler; kar kalitesi ve yapay karlama olanakları, iklim özellikleri ve uzun sezon, uzun ve çeşitli pistler, gece kayağı olanağı, ulaşılabilirlik, alternatif turizm potansiyeli, köklü kayak geçmişi, toplumsal yapı, coğrafi konum ve tanınırlık/ulusal medyada yer bulması başlıkları altında toplanmıştır (Tablo 1). Zayıf yönlerin toplandığı başlıklar; halktan kopuk turizm gelişimi, kapalı toplum yapısı, aracıların eksikliği, turist rehberi eksikliği, tanıtım ve pazarlama eksikliği başlı̆̆ altında ele alınabilecek alternatif turizm ürünlerinin tanitımda kullanılmaması ve tanitım ve pazarlama firsatlarından yararlanılmaması, bütüncül destinasyon yönetimi eksikliği, turistik ürün eksikliği, kayak pistlerinin plansızlığı, hava kirliliği, kış turizmi ürününün maliyeti, sürdürülebilir planlama/tasarım eksikliği, insan sermayesi eksikliği, merkeziyetçi karar verme süreçleri, siyasi gücün etkin kullanılamaması ve üniversitenin aktif rol oynamamasıdır (Tablo 2). 
Tablo 1. Güçlü Yönler: GZFT Analizleri sonucunda ortaya çıkan ortaklıklar \& farklılıklar.

\begin{tabular}{|c|c|c|}
\hline \multirow{2}{*}{$\begin{array}{l}\text { Gzft } \\
\text { Analizleri }\end{array}$} & Kodlanmış Bilgiye Dayalı Üretilen & Katılımlı Yöntemsel Yaklaşımla Üretilen \\
\hline & \multicolumn{2}{|l|}{ Güçlü Yönler } \\
\hline \multirow{13}{*}{ 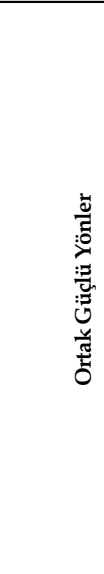 } & Kar Kalitesi \& Yapay Karlama Olanaklanı & \multirow{4}{*}{$\begin{array}{l}\text { Kar Kalitesi \& Yapay Karlama o-Olanakları } \\
\text { Çabuk erimeyen özelliği ile kar kalitesinin yüksekliği } \\
\text { (kristal kar-toz kar), } \\
\text { Suni kar yapma sistemleri olması, }\end{array}$} \\
\hline & Kar kalitesinin (toz kar) yüksekliği, & \\
\hline & Kar yapma sistemlerinin bulunması, & \\
\hline & \multirow{2}{*}{$\begin{array}{l}\text { İklim Özellikleri \& Uzun Sezon } \\
\text { Kayak sezonunun uzun olması, }\end{array}$} & \\
\hline & & \multirow{2}{*}{$\begin{array}{l}\text { İklim Özellikleri ve Uzun Sezon } \\
\text { Karı dağda kalma süresinin } 6 \text { ay olması, }\end{array}$} \\
\hline & \multirow{2}{*}{$\begin{array}{l}\text { Uzun ve Çeşitli Pistler } \\
12 \mathrm{~km} \text { 'lik tek parça pist uzunluğu ile Tür- } \\
\text { kiye'de en uzun } 1 \text {. ve dünyada en uzun 3. piste } \\
\text { sahip olmast, }\end{array}$} & \\
\hline & & $\begin{array}{l}\text { Uzun ve Çeşitli Pistler } \\
12 \text { km'lik tek pist uzunluğu ile dünyanın en uzun ilk on } \\
\text { pistinden biri olması }\end{array}$ \\
\hline & \multirow{2}{*}{$\begin{array}{l}\text { Gece Kayağı Olanağı } \\
6 \text { km'lik pistte gece kayağı yapma olanağı su- } \\
\text { nulması, }\end{array}$} & Gece Kayağ 1 Olanağı \\
\hline & & $\begin{array}{l}\text { Akşam vakitlerinde ( } 21.00^{\prime} \mathrm{e} \text { kadar) tamamen aydınlatıl } \\
\text { mş } 6 \text { km'lik pistte gece kayağı yapma olanağı olması, }\end{array}$ \\
\hline & \multirow{3}{*}{$\begin{array}{l}\text { Ulaşılabilirlik } \\
\text { Kayak merkezinin şehir merkezine } 4 \mathrm{~km} \text { ve } \\
\text { uluslararası havaalanına } 10 \mathrm{~km} \text { uzaklıkta bu- } \\
\text { lunması, }\end{array}$} & Ulaşılabilirlik \\
\hline & & $\begin{array}{l}\text { Hava alanından kayak merkezine mesafe } 15 \mathrm{~km} \text {, şehi } \\
\text { merkezinden kayak merkezine mesafenin } 8 \mathrm{~km} \text { olması, }\end{array}$ \\
\hline & & \multirow{2}{*}{$\begin{array}{l}\text { Alternatif Turizm Potansiyeli } \\
\text { Yüksek irtifa kamp merkezi ile farklı spor türleri için } \\
\text { kamp merkezine sahip olması, }\end{array}$} \\
\hline & $\begin{array}{l}\text { Alternatif Turizm Potansiyeli } \\
\text { Yüksek irtifa kamp merkezi olması, }\end{array}$ & \\
\hline \multirow{9}{*}{ 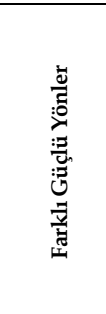 } & Kar Kalitesi \& Yapay Karlama Olanakları & \multirow{3}{*}{$\begin{array}{l}\text { İklim Özellikleri ve Uzun Sezon } \\
\text { Palandöken kayak merkezinin, kar sezonunu açan ilk kış } \\
\text { turizm merkezi olması, }\end{array}$} \\
\hline & Suni çı̆ düşürme sistemlerinin bulunması, & \\
\hline & \multirow{7}{*}{$\begin{array}{l}\text { Uzun ve Çeşitli Pistler } \\
\text { Uluslararası Kayak Federasyonu tarafından } \\
\text { tescillenmiş pistlerinin olması, } \\
\text { Farklı eğimlerdeki kayak pistlerine sahip ol- } \\
\text { ması nedeniyle her seviyeden kayakçıya hiz- } \\
\text { met verilebilmesi, }\end{array}$} & \\
\hline & & Uzun ve Çeşitli Pistler \\
\hline & & Tüm pistlerin toplam uzunluğunun $46 \mathrm{~km}$ olması, \\
\hline & & Doğal pistlerinin olması, \\
\hline & & Kayak alanının doğal manzaraya sahip olması, \\
\hline & & Ulaşılabilirlik \\
\hline & & $\begin{array}{l}\text { Kayak merkezine ulaşım ve ulaşılabilirlik kolaylığı, } \\
\text { İstanbul-Erzurum arası uçakla } 1.5 \text { saat olmass, }\end{array}$ \\
\hline
\end{tabular}

Alternatif Turizm Potansiyeli

Alternatif turizm çeşitleri için mevcut ve potansiyel ürünler bulunması,

\section{Tanınırlık}

Dünya Üniversiteler Arası Kış Olimpiyatlarına ev sahipliği yapması nedeniyle Türkiye ve dünyada bilinir-

\section{Kış Turizmi Altyapısı}

Erzurum'da Palandöken, Konaklı, Kandilli ve Gez Yaylası olmak üzere 4 adet kayak merkezi alanı bulunmasi,

Personel, arazi ve girdi maliyetlerinin nispeten düşük olmasi,

Farklı kayak merkezlerinde kış turizmi ve sporlarına yönelik çeşitli aktiviteler yapılabilmesi,

Mevcut spor tesisi yatırımları sayesinde ulusal ve uluslararası düzeyde spor organizasyonlarına ev sahipliği yapmasi,

Karar Vericilerin İlgisi

Yerel yönetimlerin kış turizmi kapsamında çalışmalar yapıyor olması,

\section{Alternatif Turizm Potansiyeli}

Erzurum'un tarihi ve kültürel turizmi ile de ön plana çıkıyor olması (Erzurum Evleri vb.), ayrıca yöresel mutfak zenginliği (kadayıf dolması, că̆ kebabi vb.),

Erzurum'un önemli Kültürel miras değerleri ile ve Doğal değerlerine sahip olması (Kiliseler, Hamamlar vb., Tortum Şelalesi, Yedigöller, Peri Bacaları vb.)

\section{Köklü Kayak Geçmişi}

Erzurum ilinin, ilk askeri kayak alanının kurulduğu yer olması ve kayağın turizmle bütünleşmesinin 90'li yllara dayanmast,

\section{Toplumsal Yapi}

Erzurum halkının sıcakkanlı ve misafirperver olmasi,

Köklü, güçlü, toplumsal güçlenmeyi yakalamış ve şehir ekonomisine katkısı olan üniversitenin öğrenci ve memur sayısının fazlalı̆̆̆,

\section{Coğrafi Konum}

Şehrin stratejik konuma sahip olması,

Tanınırlık/Ulusal Medyada Yer Bulması

Erzurumlu ünlülerin olması.

\section{Erzurum ilinde kış turizmi aynı zamanda makro çevredeki bazı firsat ve tehditlerden de etkilenmektedir. Bu bağlamda GZFT analizi sonucu ortaya}


çıan fırsatlar; sürdürülebilir planlama, ürün geliştirme ve çeşitlendirme, bölgesinde lider şehir olma, siyasal destek, ulusal yatırımların artması, düşük döviz kurları-ülke ekonomisinde iyileşme, toplumsal yapı, alternatif turizm potansiyeli, dijital platformlar, uluslararası pazarın artan önemi, ulaşım kolaylı̆̆1 ve kalitesi, ulusal plan ve politikalar başlıkları altında toplanmıştır (Tablo 3). Son olarak tehditler; politik belirsizlikler, güvenlik tehditleri, artan bölgesel rekabet, kapalı toplum yapısı, iklim değişikliğine yönelik farkındalık eksikliği, artan hava kirliliği, plansız yapılaşma, yabancı turistlere yönelik ürün eksikliği, ulaşım ve ulaşımda fiyat politikaları, bütüncül destinasyon yönetiminin olmaması, iç pazarın kaybedilmesi, devlet desteği / mevzuat eksikliği, çevresel farkındalık arttırmaya yönelik çalışmaların eksikliği, aktörler arası işbirliği eksikliği, küresel ısınma, tanıtım ve pazarlama olanaklarından yararlanılmaması, başlıkları altında toplanmıştır (Tablo 4).

\section{GZFT Analizleri Karşılaştırması}

GZFT analizlerinin karşılaştırılması sonucu ortaya çkan farklılıklar Tablo 1, 2, 3 ve 4'de sunulmuştur. Buna göre GZFT analizlerinde ortaya konulan güçlü yönler karşılaştırıldığında, ortaya çıkan ortak alt başlıkların Kar Kalitesi ve Yapay Karlama Olanakları, İklim Özellikleri ve Uzun Sezon, Uzun ve Çeşitli Pistler, Gece Kayağı Olanağı, Ulaşılabilirlik ve Alternatif Turizm Potansiyeli olduğu görülmektedir. Bu alt başlıklar altında iki GZFT analizi sonucunda da belirlenen ortak güçlü yönler bulunmaktadır. Ancak bu çalışmanın amacı doğrultusunda farklılıklara odaklanılması daha büyük önem taşımaktadır. Çünkü, katılımlı yöntemsel yaklaşım ile üretilen yerelin bilgisinin kodlanmış bilgiden farklılık gösterdiği kısımlarının yerelin kodlanmamış bilgisini, diğer bir ifade ile örtük bilgisini, oluşturduğu söylenebilir. Bu bilginin kodlanması, biriktirilebilecek ve aktarılabilecek hale getirilmesi ise günümüz bilgi toplumunda gelişme ve yaratıcllı̆̆ beraberinde getirecek önemli bir üretim ve birikim biçimidir.

Güçlü yönler bağlamında iki analiz sonucunda ortaya çıkan farklılıklar Tablo 1'de sunulmuştur. Buna göre ikincil kaynaklara bağlı olarak yapılan GZFT analizinde, katılımlı yöntemsel yaklaşım ile yapılandan farklı olarak, uzun ve çeşitli pistler, tanınırlık, kış turizmi altyapısı ve karar vericilerin ilgisi başlıkları altında güçlü yönler ortaya konulmuştur. Diğer taraftan katılımlı yaklaşımla elde edilen GZFT analizinde farklı olarak iklim özellikleri ve uzun sezon, uzun ve çeşitli pistler, ulaşılabilirlik, köklü kayak geçmişi, toplumsal yapı, coğrafi konum ve tanınırlı//ulusal medyada yer bulma başlıkları altında toplanan güçlü yönler ortaya çıkmıştır. 
GZFT analizlerinde zayıf yönler karşılaştırıldığında, ortaya çıkan ortak alt başlıkların halktan kopuk turizm gelişimi, aracıların eksikliği, bütüncül destinasyon yönetimi eksikliği, tanıtım ve pazarlama eksikliği ve hava kirliliği olduğu görülmektedir. Farklılıklara odaklanıldığında ise ikincil kaynaklara bağlı analizde kış turizmi üstyapısı ve yatırımların eksikliği, insan sermayesi eksikliği, veri toplama ve arşivleme eksikliği başlıkları altında farklı zayıf yönler olduğu görülürken; katılımlı yaklaşımla halktan kopuk turizm gelişimi, kapalı toplum yapısı, turist rehberi eksikliği, tanıtım ve pazarlama eksikliği, turistik ürün eksikliği, kayak pistlerinin plansızlığı, kış turizmi ürününün maliyeti, sürdürülebilir planlama/tasarım eksikliği, insan kaynağı, merkeziyetçi karar verme süreçleri, siyasi gücün etkin kullanılamaması ve üniversitelerin aktif rol oynamaması başlıkları altında zayıf yönler belirlenmiştir (Tablo 2).

Tablo 2. Zayıf Yönler: GZFT Analizleri sonucunda ortaya çıkan ortaklıklar \& farklılıklar.

\begin{tabular}{|c|c|c|}
\hline \multirow{2}{*}{$\begin{array}{l}\text { Gzft } \\
\text { Analiz- } \\
\text { leri }\end{array}$} & Kodlanmış Bilgiye Dayalı Üretilen & Katılımlı Yöntemsel Yaklaşımla Üretilen \\
\hline & \multicolumn{2}{|l|}{ Zayıf Yönler } \\
\hline \multirow{13}{*}{ 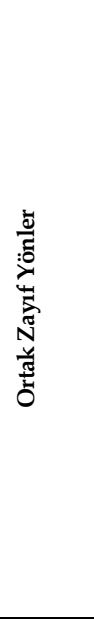 } & \multirow{3}{*}{$\begin{array}{l}\text { Halktan Kopuk Turizm Gelişimi } \\
\text { Toplumda kış turizmine yönelik farkındalı- } \\
\text { ğın olmayışı/düşüklüğ̈̈, }\end{array}$} & Halktan Kopuk Turizm Gelişimi \\
\hline & & Kış turizm kültürünün olmaması, \\
\hline & & \multirow{2}{*}{$\begin{array}{l}\text { Aracıların (Acentelerin) Eksikliği } \\
\text { Bölgede ciddi anlamda acente eksikliğinin olması, }\end{array}$} \\
\hline & \multirow{3}{*}{$\begin{array}{l}\text { Aracıların Eksikliği } \\
\text { Erzurum turizm potansiyelini kapsamlı ola- } \\
\text { rak pazarlayan tur operatörünün/lerinin bu- } \\
\text { lunmaması, }\end{array}$} & \\
\hline & & Bütüncül Destinasyon Yönetimi Eksikliği \\
\hline & & $\begin{array}{l}\text { Merkezi bir destinasyon yönetim biriminin olma- } \\
\text { ması, }\end{array}$ \\
\hline & \multirow{3}{*}{$\begin{array}{l}\text { Bütüncül Destinasyon Yönetimi Eksikliği } \\
\text { Merkezi bir destinasyon yönetim anlayışının } \\
\text { ve uzun vadeli planların eksikliği, } \\
\end{array}$} & Tanıtım ve Pazarlama Eksikliği \\
\hline & & Tanıtım ve pazarlama politikasının olmaması, \\
\hline & & \multirow{2}{*}{$\begin{array}{l}\text { Turistik ürün eksikliği } \\
\text { Kayak haricinde dağa gelen misafirlerin vakit geçire- } \\
\text { bilecekleri alternatiflerin olmaması (dağ köyü gibi ol- } \\
\text { ması), }\end{array}$} \\
\hline & $\begin{array}{l}\text { Tanıtım ve Pazarlama Eksikliği } \\
\text { Tanitım ve pazarlama faaliyetlerinin } \\
\text { yetersizliği, }\end{array}$ & \\
\hline & Turistik Ürün Eksikliği & \multirow{3}{*}{$\begin{array}{l}\text { Hava Kirliliği } \\
\text { Kayak merkezinin şehre yakınlığında hava kirliliği- } \\
\text { nin önemli bir dezavantaj oluşturuyor olması, }\end{array}$} \\
\hline & $\begin{array}{l}\text { Kayak dışında dağda eğlence aktivitelerinin } \\
\text { sınırlı olması, }\end{array}$ & \\
\hline & $\begin{array}{l}\text { Hava Kirliliği } \\
\text { Kısın yașanan hava kirliliği, }\end{array}$ & \\
\hline \multirow{10}{*}{ 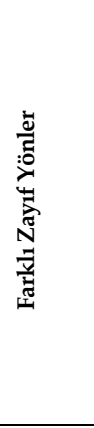 } & Kış turizmi üstyapısı \& yatırımların & \multirow{10}{*}{$\begin{array}{l}\text { Halktan kopuk turizm gelişimi } \\
\text { Toplumsal yaşamın turizme entegrasyonunun sağ- } \\
\text { lanamamış olması (Toplumsal yaşam-turizm bütün- } \\
\text { leşmesi. Turistin şehir merkezine gitmemesinde en } \\
\text { önemli nedenlerden biri dil yetersizliklerinin ol- } \\
\text { ması), Turist - halk kopukluğunun olması, } \\
\text { Kapalı Toplum Yapısı } \\
\text { Toplumda farklı eğlence türlerine karşı kapalılık ol- } \\
\text { ması, } \\
\text { Turizmin ideoloji, din, dil, ırk gibi kavramlarla ilişki- } \\
\text { lendirilmesi, } \\
\text { Uluslararası turizme hazır olunmaması, } \\
\text { Kapalı toplum yapısı, }\end{array}$} \\
\hline & eksikliği & \\
\hline & $\begin{array}{l}\text { Otel yatırımlarının ve kış turizmi tesislerinin } \\
\text { kapasitelerinin yetersizliği, }\end{array}$ & \\
\hline & İnsan Sermayesi Eksikliği & \\
\hline & Kalifiye işgücü eksikliği, & \\
\hline & $\begin{array}{l}\text { Veri Toplama \& Arşivleme eksikliği } \\
\end{array}$ & \\
\hline & İstatistiki bilginin yetersizliği, kış turizmi ile & \\
\hline & eşleştirilmemesi, & \\
\hline & & \\
\hline & & \\
\hline
\end{tabular}


Tablo 2 (devamı). Zayıf Yönler: GZFT Analizleri sonucunda ortaya çıan ortaklıklar \& farklilıklar.

\begin{tabular}{|c|c|}
\hline \multirow{2}{*}{$\begin{array}{l}\text { Gzft } \\
\text { Analiz- } \\
\text { leri }\end{array}$} & Katılımlı Yöntemsel Yaklaşımla Üretilen \\
\hline & Zayıf Yönler \\
\hline \multirow{17}{*}{ 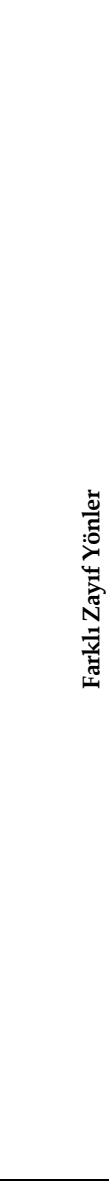 } & $\begin{array}{l}\text { Toplumun turizmi olumsuz/tehdit olarak algılaması, } \\
\text { Toplumsal yapının değişmesi, }\end{array}$ \\
\hline & $\begin{array}{l}\text { Turist Rehberi Eksikliği } \\
\text { Turist rehberlerinin olmaması, }\end{array}$ \\
\hline & $\begin{array}{l}\text { Tanıtım ve Pazarlama Eksikliği } \\
\text { Dağın 'Ejder 3200' markasının sadece operasyonel olarak kullanılıyor olması- yönetimsel an- } \\
\text { lamda eksiklik sorununu ortaya çıkartması ve markanın tanıtım yetersizliklerinden dolayı bilin- } \\
\text { memesi/ Palandökeni çağrıştırmıyor olması, }\end{array}$ \\
\hline & $\begin{array}{l}\text { Alternatif turizm ürünlerinin tanıtımda kullanılmaması } \\
\text { Pazarlama anlayışında şehrin kültürüne, mutfağına yönelik anlatımların olmayışı; gelen turist } \\
\text { profilinin sadece kayak turizmine yönelik olması, }\end{array}$ \\
\hline & $\begin{array}{l}\text { Tanıtım ve pazarlama fırsatlarından yararlanılmaması } \\
\text { Ulusal ve uluslararasındaki fuarlara katılım olmaması, (Bu sebeple Polonya'dan charter seferle- } \\
\text { rini Erciyes'in alması; bu durumun sebebi ise devlet teşviklerinin bu bölgeye olmaması), }\end{array}$ \\
\hline & $\begin{array}{l}\text { Turistik Ürün Eksikliği } \\
\text { Erzurum'a uçak seferlerinin sayısının yetersizliği ve uçak biletlerinin yüksekliği (otele verilen üc- } \\
\text { retleri bile aşıor) ve ek seferlerin olmaması, } \\
\text { Palandökende mevcut durumda eğlence merkezlerinin olmaması, }\end{array}$ \\
\hline & Kayak Pistlerinin Plansızlığı \\
\hline & Kayak pistlerinde toplanma alanlarının dar olması (bu durum göz korkutuyor), \\
\hline & $\begin{array}{l}\text { Kış Turizmi Ürünün Maliyeti } \\
\text { Gece kayağı alternatifi talep edilmeyen günlerde yapıldığından maliyetleri artırdığı için bir deza- } \\
\text { vantaj oluşturması (hafta içinde belirlenen bazı günlerde yapılıyor oluşu), }\end{array}$ \\
\hline & Sürdürülebilir Planlama/Tasarım Eksikliği \\
\hline & Kayak alanının çevresinde ağaçlandırma eksikliği olması, \\
\hline & Dogal zenginlıklerın bilınçsizce kaybediliyor olması, \\
\hline & $\begin{array}{l}\text { Insan Kaynağı } \\
\text { Kış dönemleri haricinde personel ihtiyacı sorunu olması, }\end{array}$ \\
\hline & Merkeziyetçi Karar Verme Süreçleri \\
\hline & Devlet eliyle yapılan yatırımlar sorunu (kararların tek bir merkezden verilmesi), \\
\hline & $\begin{array}{l}\text { Siyasi Gücün Etkin Kullanılamaması } \\
\text { İlin siyasi güç potansiyeli olmasına karşın siyasi yaptırımların olmayışı, }\end{array}$ \\
\hline & $\begin{array}{l}\text { Üniversitenin Aktif Rol Oynamaması } \\
\text { Üniversitenin turizm farkındalığı oluşturmada aktif rol almaması. }\end{array}$ \\
\hline
\end{tabular}

GZFT analizleri karşılaştırması sonucunda fırsatlar karşılaştıııldığında bu çalışma kapsamında yapılan sınıflandırmaya göre, ortaya çıkan ortak alt başlikların ulusal politika ve planlar, toplumsal yapı ve alternatif turizm potansiyeli olduğu görülmektedir. Ancak, bu alt başlıklar ortak olarak belirlenmiş olmasına karşın, bunların altlarında yer alan firsatlar farklılık göstermektedir İki GZFT analizindeki fırsatlar bağlamında farklılıklara odaklanıldığında ikincil kaynaklara bağlı analizde ulusal plan ve politikalar, kış turizmi pazarında iyileşme, proje ve yatırımlar, toplumsal yapı, küresel ısınma ve iklim 
değişikliği ile alternatif turizm potansiyeli başlıkları altında farklı firsatlar ortaya çıkarken; katılımlı yaklaşımla elde edilen analizde sürdürülebilir planlama, ürün geliştirme ve çeşitlendirme, bölgesinde lider şehir olma, siyasal destek, ulusal yatırımların artması, düşük döviz kurları - ülke ekonomisinde iyileşme, toplumsal yapı, alternatif turizm potansiyeli, dijital platformlar, uluslararası pazarın artan önemi, ulaşım kolaylığı ve kalitesi, ulusal plan ve politikalar başlıkları altında farklı firsatlar belirlenmiştir (Tablo 3).

Tablo 3. Fırsatlar: GZFT Analizleri sonucunda ortaya çkan ortaklıklar \& farklılıklar.

\begin{tabular}{|c|c|c|}
\hline $\begin{array}{l}\text { Gzft } \\
\text { Analizleri }\end{array}$ & Kodlanmış Bilgiye Dayalı Üretilen & Katılımlı Yöntemsel Yaklaşımla Üretilen \\
\hline Firsatlar & & \\
\hline \multirow{11}{*}{ 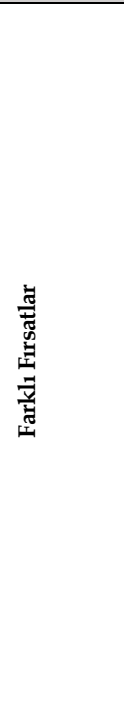 } & \multirow{3}{*}{$\begin{array}{l}\text { Ulusal Plan \& Politikalar } \\
\text { Ulusal politika alanında Erzurum `un güçlü temsili, } \\
\text { Devlet plan ve politikalarında kış turizmine yönelik } \\
\text { çalışmaların yapılması, fonlar sağlanması, }\end{array}$} & Ulusal Plan \& Politikalar \\
\hline & & $\begin{array}{l}\text { Siyasi politikaların turizmi olumlu etkile- } \\
\text { yecek yönde değişecek olması, }\end{array}$ \\
\hline & & \multirow{4}{*}{$\begin{array}{l}\text { Toplumsal Yapı } \\
\text { Bölgeye kaliteli göç olacak ve bunun tu- } \\
\text { rizme olumlu yansımalarının olacak ol- } \\
\text { ması, }\end{array}$} \\
\hline & Toplumsal Yapı & \\
\hline & Bölgedeki genç nüfus, & \\
\hline & Alternatif Turizm Potansiyeli & \\
\hline & $\begin{array}{l}\text { Turizmi tüm yıla yayma hususunda kış turizminin } \\
\text { önemli bir alternatif olması, }\end{array}$ & \multirow{5}{*}{$\begin{array}{l}\text { Alternatif Turizm Potansiyeli } \\
\text { Farklı spor dalları için Erzurum ilinin çeki- } \\
\text { ciliğinin artacak olması ve farklı dallardan } \\
\text { sporcuların bölgeye kamp için gelecek ol- } \\
\text { ması (Yüksek İrtifa Kamp Merkezi, Bu du- } \\
\text { rum özellikle turizmin } 12 \text { aya yayılması } \\
\text { konusunda oldukça önem arz etmektedir), } \\
\text { Bölgede tarihi ve kültürel değerler ön } \\
\text { plana çıkartılacak olması (Göbekli Tepe } \\
\text { gibi), } \\
\text { Alternatif turizm taleplerinde artıs olacak } \\
\text { (kongre turizmi vb.) olması, } \\
\text { Doğa ve kültür turizmine yönelik talebin } \\
\text { artacak (kuş gözlemciliği gibi) olması, }\end{array}$} \\
\hline & Kış Turizmi Pazarında İyileşme & \\
\hline & $\begin{array}{l}\text { Kış turizmi ve kış sporlarına yönelik ilginin artması, } \\
\text { İran ve Azerbaycan pazarındaki olumlu gelişmeler, }\end{array}$ & \\
\hline & $\begin{array}{l}\text { Proje \& Yatırımlar } \\
\text { Bölgedeki ulaştırma projeleri, } \\
\text { Çevre illerde kayak merkezleri olması ve bölgede Er- } \\
\text { zurum'u da içine alan kış turizmi koridoru projesinin } \\
\text { yapılıyor olması, }\end{array}$ & \\
\hline & $\begin{array}{l}\text { Küresel Isınma \& İklim Değişikliği } \\
\text { İklim değişikliği, } \\
\text { Birçok popüler kış turizmi destinasyonunda kar ka- } \\
\text { litesinin düşmesi, }\end{array}$ & \\
\hline
\end{tabular}


Tablo 3 (devamı). Fursatlar: GZFT Analizleri sonucunda ortaya çıkan ortaklıklar\&farklılıklar.

\begin{tabular}{|c|c|}
\hline \multirow{2}{*}{$\begin{array}{l}\text { Gzft } \\
\text { Analizleri }\end{array}$} & Katılımlı Yöntemsel Yaklaşımla Üretilen \\
\hline & Firsatlar \\
\hline \multirow{9}{*}{ 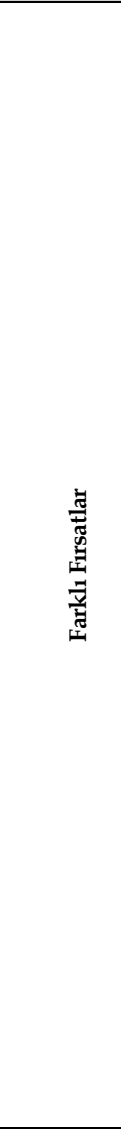 } & $\begin{array}{l}\text { Sürdürülebilir Planlama } \\
\text { Palandöken etrafındaki mevcut tesislere ek olarak herhangi bir yayılma olmayacak, odaklı tesis } \\
\text { gelişimi olacak olması, } \\
\text { Palandöken ve çevresinin daha çevreye duyarlı hale getirilebilir olması, }\end{array}$ \\
\hline & $\begin{array}{l}\text { Ürün Geliştirme \& Çeşitlendirme } \\
\text { Palandökende eğlence merkezlerinin olmasına yönelik yeni yatırımların artacak olması, } \\
\text { Kuşaklar arası geçişte devlet desteğinin eksik olması nedeniyle yeni kuşaklara göre yatırım strateji- } \\
\text { leri geliştirilecek olması (Ürün çeşitlendirme kapsamında hostel yatırımları, dijitalleşme vb.) } \\
\text { Yabancı turistlere yönelik ürün geliştirmeye yönelik pazar araştırmalarının önem kazanacak olması, }\end{array}$ \\
\hline & $\begin{array}{l}\text { Bölgesinde Lider Şehir Olması } \\
\text { Erzurum ilinin ekonomik ve kültürel açıdan bölgesel liderliğinin devam edecek, güçlenecek olması, }\end{array}$ \\
\hline & $\begin{array}{l}\text { Siyasal Destek } \\
\text { Bakanlık düzeyinde kış turizm toplantılarının Erzurum'da gerçekleştirilmesine yönelik çalışmalar } \\
\text { yürütülecek olması, }\end{array}$ \\
\hline & $\begin{array}{l}\text { Ulusal Yatırımların Artması } \\
\text { Ucuz destinasyon merkezleri küresel olarak artacak (Lift-konaklama kapasitesi dengesizliği sorunu } \\
\text { devam edecek) ve ülkesel yatırımların yüzü Erzurum'a dönecek olması, }\end{array}$ \\
\hline & $\begin{array}{l}\text { Düşük Döviz Kurları-Ülke Ekonomisinde İyileşme } \\
\text { Ülke ekonomisi iyileşecek, Euro ve Dolar değerleri düşecek ve böylece alım gücü yüksek yabancı } \\
\text { turistin bölgeyi tercih edecek olması, } \\
\text { Yurt dışından alım gücü düşük turistlerin bölgede tatil yapma durumu azalacak ve alım gücü daha } \\
\text { yüksek turist bölgeyi tercih edecek olması, }\end{array}$ \\
\hline & $\begin{array}{l}\text { Dijital Platformlar } \\
\text { (Turizmin güven ve tanıtıma dayalı olmasından hareketle) dijital platformların daha da önem kaza- } \\
\text { nacak olması, } \\
\text { Dijitalleşme ve sosyal medyanın bölgede farkındalık yaratacak olması (Örneğin Kars Doğu Ekspre- } \\
\text { sinin sosyal medyada paylaşılması ile tekrar gündeme gelmesi gibi), }\end{array}$ \\
\hline & $\begin{array}{l}\text { Uluslararası Pazarın Artan Önemi } \\
\text { Yerli turist pazarının yetersiz olmasının gelecekte de devam edecek olmasından dolayı uluslararası } \\
\text { pazarın önem kazanacak olması, }\end{array}$ \\
\hline & $\begin{array}{l}\text { Ulaşım Kolaylığı \& Kalitesi } \\
\text { Ulaşımda teknolojinin gelişmesinin turizmi olumlu yönde etkileyecek olması, } \\
\text { Şehir merkezlerinden kayak merkezlerine ulaşımın iyileşecek olması. }\end{array}$ \\
\hline
\end{tabular}

GZFT analizleri karşılaştırması sonucunda tehditler karşılaştırıldığında, ortaya çıkan ortak alt başlıkların toplumsal yapı, güvenlik tehditleri ve küresel ısınma olduğu görülmektedir. Bu alt başlıklar altında iki GZFT analizinde de ortak olarak belirlenen tehditler bulunmaktadır. Analizlerde ortaya çıkan farklı tehditlere odaklanıldığında ikincil kaynaklara bağlı analizde doğal afetler başlığı altında belirlenen çevresel afetler ile katılımlı yaklaşımla ortaya konulan politik belirsizlikler, güvenlik tehditleri, artan bölgesel rekabet, toplumsal yapı, iklim değişikliğine yönelik farkındalık eksikliği, artan hava kirliliği, plansız yapılaşma, yabancı turistlere yönelik ürün eksikliği, ulaşım ve ulaşımda fiyat politikaları, bütüncül destinasyon yönetiminin olmaması, iç pazarın kaybedilmesi, devlet desteği/mevzuat eksikliği, çevresel farkındalık arttırmaya yönelik çalışmaların eksikliği, aktörler arası işbirliği eksikliği, ve 


\section{tanitım ve pazarlama olanaklarından yararlanılması altında farklı tehditler belirlenmiştir (Tablo 4).}

Tablo 4. Tehditler: GZFT Analizleri sonucunda ortaya çıkan ortaklıklar \& farklılıklar.

\begin{tabular}{|c|c|c|}
\hline \multirow{2}{*}{$\begin{array}{l}\text { Gzft } \\
\text { Analizleri }\end{array}$} & $\begin{array}{l}\text { Kodlanmış Bilgiye } \\
\text { Dayalı Üretilen }\end{array}$ & Katılımlı Yöntemsel Yaklaşımla Üretilen \\
\hline & \multicolumn{2}{|l|}{ Tehditler } \\
\hline \multirow{6}{*}{ 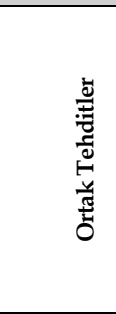 } & Küresel Isınma & Küresel Isınma \\
\hline & $\begin{array}{l}\text { Küresel ısınmanın sezonu } \\
\text { kısaltması, }\end{array}$ & $\begin{array}{l}\text { Kentsel ısı adaları ve barajların iklimi olumsuz yönde etkileyecek } \\
\text { olması, }\end{array}$ \\
\hline & Toplumsal yapı & Toplumsal Yapı \\
\hline & $\begin{array}{l}\text { Sosyal sürdürülebilirlik, } \\
\text { olası kültürel çatışmalar, }\end{array}$ & $\begin{array}{l}\text { Turizmin gelişimiyle birlikte halkın turizme entegrasyonunun sağ- } \\
\text { lanamaması sorununun gelecekte de devam edecek olması, }\end{array}$ \\
\hline & Güvenlik Tehditleri & Güvenlik Tehditleri \\
\hline & $\begin{array}{l}\text { Bölgede var olan terör } \\
\text { sorunu algısı, }\end{array}$ & $\begin{array}{l}\text { Politik anlamda yaşanan belirsizlikler devam edecek ve bunların } \\
\text { özellikle dış pazarı etkileyecek olması (terör olayları), }\end{array}$ \\
\hline \multirow{4}{*}{ 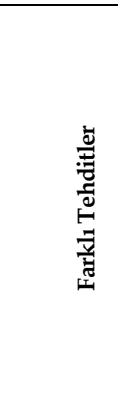 } & \multirow{4}{*}{$\begin{array}{l}\text { Doğal Afetler } \\
\text { Çevresel afetler, }\end{array}$} & $\begin{array}{l}\text { Politik belirsizlikler } \\
\text { Siyasi politikaların değişiminin turizmi olumsuz yönde etkileyecek } \\
\text { olması, }\end{array}$ \\
\hline & & $\begin{array}{l}\text { Güvenlik Tehditleri } \\
\text { Politik anlamda yaşanan belirsizliklerin devam edecek ve özellikle } \\
\text { dış pazarı etkileyecek olması, }\end{array}$ \\
\hline & & Artan Bölgesel Rekabet \\
\hline & & $\begin{array}{l}\text { Bölgenin kış turizmine yönelik örgütlenme çabasının olmaması, } \\
\text { bölgedeki kış turizm merkezleri arasında birlik olmaması, } \\
\text { Bölgede açılan yeni kış turizm merkezlerinin rekabeti artıracak ol- } \\
\text { ması, pazarın dar ve kış turizm merkezlerinin çokluğu nedeniyle re- } \\
\text { kabetin olumsuz yansıyacak olması, }\end{array}$ \\
\hline
\end{tabular}


Tablo 4 (devamı).Tehditler:GZFT Analizleri sonucunda ortaya çıkan ortaklıklar \& farklılıklar.

\begin{tabular}{|c|c|}
\hline \multirow{2}{*}{$\begin{array}{l}\text { Gzft } \\
\text { Analizleri }\end{array}$} & Katılımlı Yöntemsel Yaklaşımla Üretilen \\
\hline & Tehditler \\
\hline \multirow{15}{*}{ 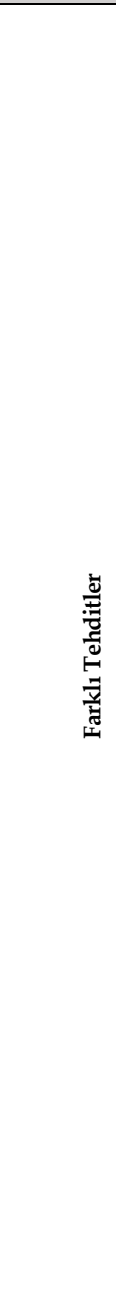 } & Toplumsal Yapı \\
\hline & $\begin{array}{l}\text { Taksicilerin yabancı dil, kılık kıyafet düzensizliği ve tavır gibi konularda yetersiz olmaları ve ha- } \\
\text { vaalanı-otel ulaşımında kaçak transferlerin turizmi etkileyecek olması, }\end{array}$ \\
\hline & İklim değişikliğine yönelik farkındalık eksikliği \\
\hline & İklim değişikliğine yönelik mikro/makro düzeyde farkındalık olmaması, \\
\hline & $\begin{array}{l}\text { Artan Hava Kirliği } \\
\text { Hava kirliliğinin artacak olması, bunun Türkiye'deki tüm kış turizm merkezlerini etkileyecek ol- } \\
\text { ması. Isınma, araç yoğunluğu, Erzurum ilinin yerleşimi gibi nedenlerle mevcutta var olan hava } \\
\text { kirliliğinin artacak olması ve bu durum yerli ve yabancı turistleri olumsuz etkileyecek olması, }\end{array}$ \\
\hline & $\begin{array}{l}\text { Plansız Yapılaşma } \\
\text { Kayak merkezlerindeki yanlış yapılanma, tesislerin yanlış konumlandırılması ve pistlere yakın } \\
\text { noktalarda yapılan yapılaşmaların devam edecek olması, } \\
\text { Planlama eksikliği nedeniyle Palandöken çevresinde yapılaşmaların artacak olması, }\end{array}$ \\
\hline & $\begin{array}{l}\text { Yabancı Turistlere Yönelik Ürün Eksikliği } \\
\text { Eğlence merkezlerinin yetersiz olması nedeniyle ulaşılabilirliği yüksek ve eğlence merkezlerine } \\
\text { sahip olan destinasyonların daha fazla turist çekecek (Uludağ gibi) olması, }\end{array}$ \\
\hline & $\begin{array}{l}\text { Ulaşım ve Ulaşımda Fiyat Politikaları } \\
\text { Fiyat politikaları nedeniyle charter seferlerinin yapılmaması ve bunun sonucunda mevcut Rus } \\
\text { pazarının kaybedilecek olması, } \\
\text { Uçak firmalarının bölgeye yönelik yeterli sayıda sefer düzenlememeleri ve pahalı uçak biletleri- } \\
\text { nin uçakla ulaşımı zorlaştıracak olması, }\end{array}$ \\
\hline & Bütüncül destinasyon yönetiminin olmaması \\
\hline & $\begin{array}{l}\text { Kamu/özel sektör destinasyon rekabetinden kaynaklanan çatışmanın devam edecek olması, } \\
\text { Ejder } 3200 \text { için önemli yatırımlar yapılmış olmasına karşın tesisler arası iletişim kopukluğunun } \\
\text { devam edecek olması, } \\
\text { Destinasyon yönetim merkezinin olmaması; oteller bireysel yönetiliyor ve gelecekte de bunun } \\
\text { devam edecek olması, }\end{array}$ \\
\hline & $\begin{array}{l}\text { İç Pazarın Kaybedilmesi } \\
\text { İç pazardaki taleplerin yurt dışına doğru kayacak olması, } \\
\end{array}$ \\
\hline & $\begin{array}{l}\text { Devlet Desteği / Mevzuat eksikliği } \\
\text { Kış turizminde devlet desteğinin eksikliğinin olumsuz etkileyecek olması, } \\
\text { Turizme yönelik mevzuat eksikliğinin destinasyonları olumsuz etkileyecek olması, }\end{array}$ \\
\hline & $\begin{array}{l}\text { Çevresel farkındalık arttırmaya yönelik çalışmaların eksikliği } \\
\text { Çevresel farkındalığa yönelik çalışmaların yetersiz olması, }\end{array}$ \\
\hline & $\begin{array}{l}\text { Aktörleri arası işbirliği eksikliği } \\
\text { Bilim/sektör/politika işbirliğinin eksik olması, }\end{array}$ \\
\hline & $\begin{array}{l}\text { Tanıtım ve pazarlama olanaklarından yararlanılmaması } \\
\text { Ulusal ve uluslararası platformlarda gerçekleştirilen fuarlara katılım sağlanmıyor olması. }\end{array}$ \\
\hline
\end{tabular}

\section{Sonuç ve Değerlendirme}

Bu çalışmada biri kodlanmış bilgiye, diğeri ise yerelin bilgisine dayalı olarak aynı amaç doğrultusunda üretilen iki GZFT analizi karşılaştırılmıştır. Bu yolla çalışmada, bilginin sadece bilen özneden ayrılmış, nesnel ve tarafsız olarak ele alınışından uzaklaşılmış olduğu günümüzde dünyasında, Prof. Dr. İlhan Tekeli tarafindan demokratik bir insan hakkı olarak tanımlanan, katılım 
yoluyla üretilen yerelin bilgisi ile kodlanmış bilginin farkının ortaya konulması amaçlanmıştır.

Çalışmanın sonucunda yerelin bilgisi ile üretilen GZFT analizinde, bilimsel bilgiye dayalı olarak üretilen GZFT analizine kıyasla, özellikle zayıf yönler, firsatlar ve tehditler anlaminda niceliksel ve niteliksel olarak daha fazla bilginin üretildiği görülmüştür. Aynı zamanda katılımlı yaklaşımla üretilen GZFT analizi içerik olarak daha geniş bir alanı kapsamaktadır. Bu bağlamda üretilen yerelin bilgisi içerisinde, ikincil kaynaklara dayalı olarak üretilen bilgiden farklı olarak, özellikle topluma ve toplumsal yapıya ilişkin (halkın s1cakkanlı ve misafirperver olması, Erzurum'lu ünlülerin olması, turist-halk kopukluğunun olması vb.), gündelik yaşam ve deneyimlere dayalı (kayak alanının doğal manzaraya sahip olması, kayak pistlerinde toplanma alanlarının dar olması, İstanbul - Erzurum'un uçakla 1.5 saat olması, dijital platformlar vb.) bilginin; ve ulusal ve uluslararası alanda yaşanan güncel gelişmelere dayalı (düşük döviz kurları, ülke ekonomisinde iyileşme vb.) örtük bilginin ortaya çıkarıldığı görülmektedir. Bilimsel bilgiye dayalı olarak yapılan GZFT analizinde ise farklı olarak istatistiki veriye dayalı olarak açıklanabilecek (otel yatırımlarının ve kış turizmi tesislerinin kapasitelerinin yetersizliği, birçok popüler kış turizmi destinasyonunda kar kalitesinin düşmesi vb.) bilgilerin ve örnek alan ile ilgili teknik detaylara ilişkin (Uluslararası Kayak Federasyonu tarafından tescillenmiş pistlerinin olması, suni çı̆̆ düşürme sistemlerinin bulunması vb.) bilgilerin yer aldığı görülmektedir. Bunlarla birlikte ikincil kaynaklarda yer alan kodlanmış bilgiye dayalı olarak hazırlanan GZFT analizinde araştırmacının araştırma, ilgili kaynaklara ulaşma ve bilgiyi aktarma kapasitesi ve bu kapasitedeki sınırllıklarının ortaya çıkan ürünün kalitesine etki ettiği de ortadadır.

Ortak güçlü yönler arasında yer alan alternatif turizm potansiyeli örneğinde görüldüğü gibi, katılımlı yöntemsel yaklaşımla üretilen bilgi yerelin değerlerini yerelin bakış açısı ile yansıtırken, kodlanmış bilgi araştırmacı tarafından indirgenmiş ve genelleştirilmiştir. Bu durum nesnellik iddiası taşıyan bilimsel bilginin araştırmacının öznel bakış açısı ve yorumundan soyutlanmasının her zaman mümkün olamayacağının göstergesi niteliğindedir. Bu nedenle de, bu çalışma kapsamında karşılaştırılan nesnel bilgiye dayalı GZFT analizinin öznellik içerdiği, yerelin bilgisine dayalı GZFT analizinin ise bilgi üretim sürecine katılan aktörlerin öznellerarası uzlaşmasına dayandığı belirtilmelidir. 
Diğer taraftan, bu çalışmada aynı amaçla üretilen GZFT analizleri üzerinden ortaya konulduğu üzere katılımlı bilgi üretme süreçlerinde ortaya çıkarılan bilginin tamamı örtük bilgiden oluşmamaktadır. Çalışmada 2 farklı yaklaşımla üretilen GZFT analizinde görülen ortaklıklar katılımlı süreçte örtük bilgi ile birlikte kodlanmış bilginin de ortaya konulduğunu göstermektedir. Buradan hareketle de katılımlı yöntemsel yaklaşımla üretilen GZFT analizinin, kodlanmış bilgiye bağlı olarak üretilen GZFT analizinden farklı olarak ortaya koyduğu bilginin yerelin bilgisi olduğu söylenebilir. Diğer taraftan katılımlı süreçleri sadece ortaya çıkarılan yerelin bilgisi ve bu bilginin kalitesi üzerinden değerlendirmek indirgeyici bir yaklaşım olacaktır. Çünkü kattlımlı süreçlerin başka getirileri de olmaktadır. Bu getirileri çalışmanın amacı doğrultusunda bilgi üzerinden değerlendirdiğimizde, öncelikle örtük bilgiye verilen önem arttıkça, bu bilginin üretilmesi ve öğrenilmesinde en etkili değişken olarak yerelliğe verilen önemin artacağına vurgu yapılmalıdır. Yerelde birlikte üretilen ve paylaşılan bilgi karşılıklı güveni arttıracaktır. Ayrıca bilgi üretme sürecinde yakınlık kurulacak, bu yakınlık sonraki deneyimlerde öğrenme sürecini hızlandıracak; karşılıklı yarar, sinerji ve sosyal ilişki ağlarının kurulmasını sağlayacaktır.

Ancak örtük bilgi üretme sürecinde bu faydaları beraberinde getirebilmesi için süreçte katılımın araçsallaşmaması, amaç olarak kavramsallaştırılarak gerçekleştirilmesi gerekmektedir. Çünkü ülkemizde katılımın araçsal akılcılık temelinde kullanılarak araçsallaştı̆̆ pratikler nedeniyle Tekeli'nin (2014) de altını çizdiği gibi katılımın "içeriği önemli ölçüde boşalmıştır". Ancak katılımın bugüne kadar yeterince başarılamamış olması ve/veya araçsallaşmış katılımlı pratikleri deneyimleyenler arasında katılımına inancın azalmış olması katılımdan vazgeçmeyi gerektirmemektedir. Bunun yerine katılım hem günümüz bilgi toplumunda kodlanmış bilgi ile birlikte varlığı kabul edilen ve önemi anlaşılmış olan kodlanmamış bilginin ortaya çıkarılmasında kullanılacak yöntemsel bir yaklaşım hem de gerçekleştirilmesi günümüz dünyasında zorunlu olan demokratik bir insan hakkı olarak kabul edilmelidir. Bunun için de katılımlı bilgi üretme ve karar verme süreçleri özenle tasarlanmalı, katılımcların yaratıcılıklarını güç unsurlarından arınmış bir şekilde paylaştıkları, karşılıklı güven ve sosyal ilişki ağlarının kurulduğu bir faaliyet olarak deneyimlenmesi sağlanmalıdır. 


\section{Extended Abstract}

\section{Determining Difference of Implicit Knowledge Obtained through Participatory Approach with Coded Knowledge}

Neslihan Kulözü-Uzunboy ORCID: 0000-0002-1945-2635

\author{
Gürel Çetin \\ ORCID: 0000-0003-3568-6527
}

O. Cenk Demiroğlu

ORCID: 0000-0001-7012-4111

One of the scenarios used to explain the multi-faceted transformation process of today's world is the transition from Industrial Society to Information Society, which has a central position in other scenarios. The life patterns of people are redefined with the impact of changes in the transition from the industrial society to the information society. Moreover, the quality of production and the organizational form of the society are changing. As a result, the way of establishing the relationship between knowledge and production is altering and steps are taken to understand knowledge in relation to the person who knows it. This study focuses on coded knowledge, implicit knowledge, and participatory information production processes in the framework of understanding the relation of knowledge to the knower. From this point of view, the study is based on the assumption that the implicit knowledge obtained in the of knowledge generation process, in which participation, defined as a democratic human right in today's world, is adopted as a methodical approach, will be different from coded knowledge.

Paralel to the transition from the industrial society to the information society, the changes such as the transition from instrumental rationality to communicative rationality has been realized. In this transition process, the importance of implicit knowledge, which cannot be easily separated from its own, unlike scientific knowledge, is understoodThis transition can also be called transition from objective knowledge to knowledge of intersubjective consensus. Accordingly, after the second half of the 1960s, planning approaches that prioritize local participation and thus achieve intersubjective consensus and communicative rationality began to be accepted. In other 
words, participation has started to be given important roles in planning and other knowledge generation and decision-making processes. Accordingly, one of the planning approaches developed after the 1960s, where participation was conceptualized as a goal, is the strategic planning approach.

Strategic planning approach in the field of planning was redefined as a result of developments such as the prevalence of neoliberal policies in the world and the spread of postmodernist movements. Comparing to other planning approaches developed so far, different features of the strategic planning include participation of different community groups in the planning process and the SWOT (Strengths-Weaknesses-Opportunities-Threats) analysis. Today, one's participation in decisions regarding himself/herself and his/her environment is recognized as a democratic right. In this context, participation means the realization of communicative rationality and exposing the implicit knowledge as a way to achieve intersubjective consensus in the process of producing all kinds of decisions and knowledge. On the other hand, SWOT analysis is a systematic analysis of the strengths and weaknesses in the internal environment and opportunities and threats in the external environment, in other words, outside the settlement. Strengths, weaknesses, opportunities and threats not only refer to spatial conditions, but may be related to all areas such as natural, social, cultural, economic, technological, legal and administrative environments.

In this study, SWOT analyses produced at different stages of the project, titled "Determination of Winter Tourism Adaptation Strategies in Erzurum with a Participatory Approach", are presented as an example. Within the scope of the project, a strategic planning approach is followed. In this context, the current situation of winter tourism in Erzurum was determined in the first stage of the project, and SWOT analysis was conducted in order to present the obtained knowledge in a systematic way and to be used as a guide in the later stages of the project. On the other hand, actors of the winter tourism sector in Erzurum have been identified as the second stage of the strategic planning approach. Then, with the participation of the actors, a focus group study was conducted to analyze the current situation of winter tourism in Erzurum. In the workshop organized within this scope, the generated knowledge with the participatory approach was organized by the SWOT analysis method. Therefore, two different SWOT analyses were produced; the first one based on secondary sources, and the second one based on the knowledge of the local with the participation of actors. The aim of this study is to reveal how participation in knowledge generation 
process and the generated implicit knowledge make a difference by comparing the SWOT analyses, which are produced independently from each other, through different sources of information but with the same purposes. The SWOT analyses presented within the scope of the study were considered as a means of comparison. The focus of the study is not the content of the SWOT analyses, but how they differ.

As a result of the study, in the SWOT analysis produced with the knowledge of the local, it was observed that quantitatively and qualitatively more knowledge was produced, especially in terms of weaknesses, opportunities and threats compared to the SWOT analysis based on secondary sources. At the same time, SWOT analysis produced with a participatory approach covers a wider scope in content. In addition, with this study, it was revealed that while SWOT analysis produced based on objective knowledge includes subjectivity, the SWOT analysis based on local knowledge is based on the intersubjective consensus of the actors participating in the knowledge generation process.

\section{Kaynakça/References}

Altaş, N., Çavuş, A. ve Zaman, N. (2015). Türkiye'nin kış turizmi koridorunda yeni bir kış turizm merkezi: Konaklı. Marmara Coğrafya Dergisi, 31, 345-365.

Bayraktar, Y., Aksakallı Z. ve Selçuk, N. (2017). Yeni turistik ürün olarak futbol-kamp turizmi: Erzurum Yüksek İrtifa Kampı örneği. Uluslararası Türk Dünyası Araştırmaları Dergisi, 2(2), 199-210.

Bryson J.M. ve Roering W.D. (1987). Appliying private-sector strategic planning in the public sector. Journal of American Planning Association, 53(1), 9-22.

Burke, E.M. (1979). A participatory appoach to urban planning. New York: Human Services Press.

Büyükşehir Belediye Erzurum Spor. (t.y) Erzurum Yüksek İrtifa Kamp Merkezi. 27.08.2019 tarihindewww.bberzurumspor.com/tesisler/ adresinden erişilmiştir.

Cooke, B. ve Kothari, U. (2001). The case for participation as Tyranny. B. Cooke \& U. Kothari (Der.), Participation: the New Tyranny? içinde (s.1-15). London: Zed Books.

Çetin, G., ve Demiroğlu, C. (2017). Future of winter tourism in Turkey: Destination strategies for the Erzurum Erzincan Kars winter tourism corridor (WTC). The Future of Winter Tourism Congress Proceedings, 3-5 Nisan 2017, Rovaniemi, Finlandiya. Ejder3200 Word Ski Center (t.y). 11.09.2019 tarihinden https://www.ejder3200.com/. Adresinden erişilmiştir. 
Elmas, B., Akkuş, Ç. ve Cengiz, G. (2013). Erzurum İli temel ve destekleyici turistik ürün çeşitlerinin değerlendirilmesi. LAÜ Sosyal Bilimler Dergisi. 4(1), 84-109.

Ersoy, M. (2017). Planlama kuramları. S.S. Özdemir, Ö.B. Özdemir-Sarı, N. Uzun (Der.), Kent Planlama içinde (s.127-161). Ankara: İmge Yayınları.

Gedikli, B. (2012). Stratejik mekansal planlama: planlamada yeni anlayışlar, yöntemler, teknikler. M. Ersoy (Der.), Kentsel Planlama Kuramlar içinde (s.237-289). Ankara: İmge Yayınları.

Hellström, T. ve Raman, S. (2001). The commodification of knowledge about knowledge: Knowledge management and the reification of epistemology. Social epistemology: A Journal of Knowledge, Culture and Policy, 15(3), 139-154.

Koca, H., Zaman, S. ve Coşkun, O. (2007). Erzurum'un spor-kamp turizmi potansiyeli. Doğu Coğrafya Dergisi, 12(18), 205-224.

Korgavuş, B. (2017). Erzurum Palandöken'in kış turizmi açısından değerlendirilmesi. ATA Planlama ve Tasarm Dergisi 1(1). 11.09.2019 tarihnde https://dergipark.org.tr/tr/download/article-file/505478. adresinden erişilmiştir.

Koşan, A. ve Güneş, E. (2008). Erzurum, Ağrı ve Van. Gürhan Aktaş (Der.), Türkiye Turizm Coğrafyası içinde (s. 447-468). Ankara: Detay Yayıncılık.

KUDAKA. (2014). Erzurum İli turizm sektörü raporu. 04.12.2018 tarihinde http://erzurumdayatirim.kudaka.org.tr/dokumanlar/Erzurum_Turizm_Sektoru_Raporu_Ozet.pdf adresinden erişilmiştir.

KUDAKA (2019a). Kış turizmi. 11.08.2019 tarihinde http://erzurumdayatirim.kudaka.org.tr/?page_id=289 adresinden erişilmiştir.

KUDAKA (2019b), Termal ve sağlık turizmi. 27.08.2019. tarihinde http://erzurumdayatirim.kudaka.org.tr/?page_id=294 adresinden erişilmiştir.

KUDAKA (2019c). Erzurum'da yatırm. 11.10.2019 tarihinde .http://erzurumdayatirim.kudaka.org.tr/?page_id=298 adresinden erişilmiştir.

KUDAKA (2018). Erzurum kış turizmi değerlendirme raporu. 27.10.2019 tarihinde https://www.kudaka.org.tr/ekler/e4520-Erzurum-Kis-Turizmi-DegerlendirmeRaporu.pdf adresinden erişilmiştir.

Kulözü, N. (2011). Planlamaya katılım: Araç mı, amaç mı?. KBAM Kentsel ve Bölgesel Araştırmalar 2. Sempozyumu, Planlamanın Dünü, Bugünü, Yarmı: Planlamada Yeni Söylem Arayışları, 8-9 Aralık 2011, Ankara, Türkiye, s.159-170.

Kulözü, N. (2012). 5747 sayılı kanunun ardından Seyrek (İzmir): “Seyrek' in Kadınları Seyrek'i Geri İstiyor". KBAM Kentsel ve Bölgesel Araştırmalar 3. Sempozyumu, Kent Bölgeler, Metropolitan Alanlar ve Büyükşehirler "Değişen Dinamikler ve Sorunlar", 6-7 Aralık 2012, Ankara, Türkiye, s. 181-196.

Kulözü, N., (2014). Different participant groups, different success definitions: An exploratory study in the case of local government and ngo cooperation in participatory democracy project. Boğazici Journal, Review of Social, Economic and Administrative Studies, 28(1), 47-67. 
Kulözü, N. (2015a). Place of natural environmental 1ssues in curriculums of city and regional planning departments at Turkish Universities. R. Efe, M. Ayışı̆̆ı, Ö. Düzbakar ve M. Arslan (Der.), Turkey at the beginning of 21st Century: Past and Present içinde (s.438-455). Sofia: St. Kliment Ohridski University Press.

Kulözü, N. (2015b). Building a modern city on historical city space the case of Erzurum Turkey. International Conference on 'Cities, People and Places', 26-28 Ekim 2015, Colombo, Sri Lanka, s. 184-194.

Kulözü, N. (2016a). Communication as a Socio-psychological dimension of participatory planning processes: The cases of the participatory processes of Gazi, Kaymaklı, Odunpazarı \& Seyrek from Turkey. International Planning Studies, 21(2), 207223.

Kulözü, N. (2016b). Participation as a means to an end or as an end in itself: the Success Evaluations of Participants. Turkish Public Administration Annual, 41-42, 83-102.

Kulözü-Uzunboy, N. (2017). Artificial 1dentity elements of a historical city as cultural accumulation of civilizations: Erzurum, a case from Asia Minor. International Journal of Social Science and Humanity, 7, 252-259.

Kulözü, N. ve Tekeli, İ. (2014) Socio-Psychological Factors Affecting the Participatory Planning Processes at Interactional Level, MEGARON / Yıldız Teknik Üniversitesi, Mimarlik Fakültesi E-Dergisi, 1, 1-13.

Pretty, J. (1995). Regenerating agriculture. Policies and practice for sustainability and self reliance. London: Earthscan Publications Ltd.

Luque, E. (2001). Whose knowledge (economy)? Social Epistemology: A Journal of Knowledge, Culture and Policy, 15(3), 187-200.

Sayer, A. (2010). Methods in social science: A realist approach. Routledge: London.

Soyak, M. (2013). Uluslararası turizmde son eğilimler ve Türkiye' de turizm politikalarının evrimi. Marmara Sosyal Araştırmalar Dergisi, 4, 1-18.

Stiglitz, J. (1999). Scan globally, reinvent locally: Knowledge infrastructure and the localization of knowledge. First Global Development Network Conference. 25.01.2020 tarihinde https:/www0.gsb.columbia.edu/mygsb/faculty/research/pubfiles/1491/Stiglitz_ScanGlobally.pdf adresinden erişilmiştir.

T. C. Erzurum Valiliği İl Kültür ve Turizm Müdürlüğü. (t.y). Tanıtıcı materyaller:Erzurum turizm rehberi broşür. 11.09.2019 tarihinde http://erzurum.ktb.gov.tr/Eklenti/61588, turizmrehberipdf.pdf?0 adresinden erişilmiştir.

T.C. Erzurum Valiliği. Coğrafi Yapı. (t.y). 03.12.2018 tarihinde http://www.erzurum.gov.tr/cografi-yapi adresinden erişilmiştir.

T.C. Erzurum Valiliği. Palandöken ve Kayak. (t.y). 31.08 .2019 tarihinde http://www.erzurum.gov.tr/palandoken-ve-kayak. adresinden erişilmiştir.

Tekeli, İ. (1991). Kent planlaması ve katılım üzerine düşünceler. Planlama Dergisi, 91(34) , 8-13.

Tekeli, İ. (2010). Bilgi toplumuna geçerken farklılaşan bilgiye ilişkin kavram alanı üzerinde bazı saptamalar. İ. Tekeli (Der.), Mekânsal ve Toplumsal Olanın Bilgibilimi Yazıları içinde (s. 109-138). İstanbul: Tarih Vakfı Yurt Yayınları. 
Tekeli, İ. (2012). Türkiye kent planlamasının yeniden kurumsallaşmasını düzenlerken düşünülmesi gerekenler üzerine. Planlama Dergisi, 3-4, 25-32.

Tekeli, İ. (2014). Türkiye demokrasi krizini aşmadan kentlerdeki sorunlarını aşamaz, yaşam kalitesini geliştiremez. Mimarlk Dergisi, 375. 26.01.2020 tarihinde http://www.mimarlikdergisi.com/index.cfm?sayfa=mimarlik\&DergiSayi $=389 \&$ RecID $=3294$ adresinden erişilmiştir.

Üniversite Sporları Federasyonu. (2011). 25. Dünya Üniversite Kış Oyunları sonuçlar \& rapor. 12.09.2019 tarihinde http://www.univspor.org.tr/images/stories/universiade/kis/2011.pdf adresinden erişilmiştir.

Yurttaş, H., Özkan, H., Köşklü, Z., Tali, Ş., Okuyucu, D., Geyik, G. ve Kındığılı, M. (2008). Yolların, sularm ve sanatm buluştuğu şehir Erzurum. Erzurum: Atatürk Üniversitesi. 